\title{
Induction of the acrosome reaction test to in vitro estimate embryo production in Nelore cattle
}

\author{
[Teste de indução da reação acrossomal na estimativa de produção in vitro \\ de embriões Nelore] \\ M.Z. Costa, L.Z. Oliveira, M.V. Resende, A.C. Lucio, A.P. Perini, \\ M.C.V. Miguel, V.F.M.H. Lima* \\ Faculdade de Ciências Agrárias e Veterinárias - UNESP \\ Via de Acesso Prof. Paulo Donato Castellane s/n \\ 14884-900 - Jaboticabal, SP
}

\begin{abstract}
The effectiveness of induction of the acrosome reaction (AR) test as a parameter to in vitro estimate embryo production (IVP) in Nelore breed and the AR pattern by the Trypan Blue/Giemsa (TB) stain were evaluated. Frozen semen samples from ten Nelore bulls were submitted to AR induction and were also evaluated for cleavage and blastocyst rates. The treatments utilized for AR induction were: control (TALP medium), TH (TALP medium $+10 \mu \mathrm{g}$ heparin), TL (TALP medium $+100 \mu \mathrm{g}$ lysophosphatidylcholine) and THL (TALP medium $+10 \mu \mathrm{g}$ heparin $+100 \mu \mathrm{g}$ lysophosphatidylcholine). Sperm acrosomal status and viability were evaluated by TB staining at 0 and after $4 \mathrm{~h}$ incubation at $38^{\circ} \mathrm{C}$. The results obtained for $\mathrm{AR}$ presented a significant difference $(\mathrm{P}<0.05)$ in the percentage of acrosome reacted live sperm after $4 \mathrm{~h}$ of incubation in the treatments that received heparin. The cleavage and blastocyst rates were $60 \%$ and $38 \%$ respectively and a significant difference was observed among bulls $(\mathrm{P}<0.05)$. It was founded a satisfactory model to estimate the cleavage and blastocyst rates by AR induction test. Therefore, it can be concluded that the induction of the AR test is a valuable tool to predict the IVP in Nelore breed.
\end{abstract}

Keywords: cattle, fertility, semen, acrosome reaction, fertilization

\section{RESUMO}

Avaliou-se a eficiência da técnica de indução da reação acrossomal (RA) como parâmetro para estimar a produção in vitro (PIV) de embriões Nelore e analisou-se o padrão de RA pela técnica de coloração Azul de Tripan/Giemsa (TB). Amostras de sêmen congelado de dez touros foram submetidas à indução da $R A$ $e$ avaliadas quanto a taxa de clivagem e blastocisto. Os tratamentos utilizados para indução da RA

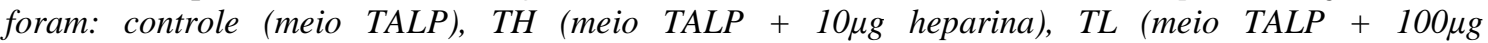
lisofosfatidilcolina) e THL (meio TALP $+10 \mu \mathrm{g}$ heparina $+100 \mu \mathrm{g}$ lisofosfatidilcolina). Avaliou-se viabilidade espermática e acrossomal pela coloração TB a zero e após 4 h de incubação a $38^{\circ} \mathrm{C}$. $\mathrm{Os}$ resultados obtidos para $R A$ mostram uma diferença significativa $(P<0,05)$ na porcentagem de espermatozoides vivos com acrossoma reagindo após 4 h de incubação nos tratamentos que receberam heparina. As taxas de clivagem e blastocisto obtidas foram $60 \%$ e 38\% respectivamente e observou-se uma diferença significativa entre touros $(P<0,05)$. Delineou-se um modelo satisfatório para estimar as taxas de clivagem e blastocisto. Desta forma, conclui-se que o teste de indução da RA é uma ferramenta valiosa para predizer a PIV na raça Nelore.

Palavras-chave: bovino, fertilidade, sêmen, reação acrossomal, fertilização

Recebido em 9 de março de 2009

Aceito em 16 de julho de 2010

*Autor para correspondência (corresponding author)

E-mail: veralima@fcav.unesp.br 


\section{INTRODUCTION}

It is well established that the sire can have a major effect on the outcome of in vitro fertilization (IVF) (Hillery et al., 1990) and in terms of cleavage rates and blastocyst yield among semen samples from different bulls (Ward et al., 2001; 2003). Those parameters can be used as important indicators for in vitro bull fertility. In the animal improvement programs which utilize in vitro production of embryos (IVP) as a genetic multiplication tool, the utilization of a predictive method for cleavage rates and IVP of a particular bull semen samples is important for saving laboratory time and unnecessary procedural costs.

When frozen semen from bulls with high field fertility was compared with that from bulls of low field fertility, a significant difference between the two groups was found in both cleavage and blastocyst yield (Zhang et al., 1997).

The ability in predicting the fertility of semen with laboratory tests is still limited, mainly due the complexity of the sperm and the fertilization process. Therefore, it is necessary to enhance the prediction of bull fertility with other tests in order to increase the accuracy of their reproductive potential estimative.

One of the key processes in mammalian fertilization is the acrosome reaction (AR) usually triggered in spermatozoa upon their binding to the zona pellucida of the egg. The AR involves fusion between the plasma membrane and the underlying outer acrosomal membrane, as a result of which the acrosomal contents are released.

The AR can be induced by either natural inducers as zona pellucida (Florman, 1994) and progesterone (Oehninger et al., 1994) or artificial inducers as heparin (Parrish et al., 1988; Kitiyanant et al., 2002), lysophosphatidylcholine (Parrish et al., 1988) and calcium ionophore (Christensen et al., 1996; Kitiyanant et al., 2002).

Utilization of the in vitro induction of the $\mathrm{AR}$ test as described by Januskauskas et al. (2000a,b) and greater implementation of IVF techniques have stimulated interest in evaluating the fertilizing potential of Nelore semen using this particular in vitro combination.

The IVF employment with this aim has been widely studied being already established in the literature the importance of this technique, besides the high costs involved. As well, significant correlations are described between AR responsiveness and fertility (Januskauskas et al., 2000a,b; Stahr et al., 2000).

Nowadays, several methods have been used as an attempt to predict the potential fertility of semen. One is trying to estimate the potential fertility of a semen sample, with has not been successfully done to date. Conventional viability tests included sperm morphology, motility, acrosome integrity, and abnormal DNA condensation. Methods for evaluation of the sperm plasmalemma included eosin/nigrosin (EN) and trypan-blue vital stains, propidium iodide (PI) in combination with carboxyfluorescein diacetate (CFDA) or SYBR-14 (SYBR) fluorescent vital stains, and the hypoosmotic swelling test (HOST) (Brito et al., 2003). Innovations in stains techniques have offered new means of spermatozoa functionality evaluation in several species (Garner and Johnson, 1995; Arruda et al., 2002; Celeghini et al., 2005). However, some costly equipment is necessary.

The Trypan-Blue/Giemsa stain (TB) was used to evaluate the efficiency of the sperm AR induction in estimating IVP from oocytes of Nelore cattle. This staining method of sperm evaluation is easy, less expensive, and efficient and could be used as a test for predicting the potential fertility of bovine (Kitiyanant et al., 2002; Tartaglione and Ritta, 2004) and equine semen samples (Kutvolgyi et al., 2006). Still in relation to TB staining, Kovacs and Foote (1992) also stated that simultaneous evaluation of the viability and acrosome integrity of sperm allows differentiation of true acrosome reaction from degenerative acrosome loss after cell death.

The aim of the present work was to evaluate, in Nelore breed bulls, the efficiency of the induction of the AR technique as a parameter to estimate the IVP and the acrosomal reaction pattern by TB stain. 


\section{MATERIAL AND METHODS}

Frozen semen samples of ten Nelore bulls were evaluated. Straws from six different batches (six different ejaculates) of each bull were thawed by immersion in water-bath at $35^{\circ} \mathrm{C}$ for $30 \mathrm{sec}$ and homogenized. The sperm were evaluated to sperm progressive motility and vigor. In order to remove the extender, the samples were washed three times in TALP medium with BSA-V (Sigma A-2153) under centrifugation $(250 \mathrm{x} \mathrm{g}$ during 10min). After the last wash, the sediment was suspended in $4 \mathrm{~mL}$ of TALP medium and the motility and vigor were evaluated again. Afterward, the semen concentration was determined from a $20 \mu \mathrm{L}$ sample in Neubauer Count and adjusted to $20 \times 10^{6} \mathrm{sperm} / \mathrm{mL}$.

The semen samples were submitted to different treatments: control (TALP medium), TH (TALP medium $+10 \mu \mathrm{g}$ heparin), TL (TALP medium + $100 \mu \mathrm{g}$ lysophosphatidylcholine; LPC) and THL $($ TALP medium $+10 \mu \mathrm{g}$ heparin $+100 \mu \mathrm{g}$ LPC $)$. The heparin (Sigma H-9399) in the final concentration of $10 \mu \mathrm{g} / \mathrm{mL}$ was utilized to induce the in vitro sperm capacitation and the LPC (Sigma L-5004) in the final concentration of $100 \mu \mathrm{g} / \mathrm{mL}$ was utilized in order to induce the acrosomal reaction. Both were prepared according to Parrish et al. (1988). In the beginning of incubation $(0 \mathrm{~h})$, the LPC was added in tubes $(5 \mu \mathrm{g} /$ microtube) and after $4 \mathrm{~h}$ of incubation, it was added to other four tubes. At each hour of reaction sperm were microscopically evaluated on heated slides $\left(\sim 37.5^{\circ} \mathrm{C}\right)$ under a coverslip for motility and vigor. The tubes with one of the four treatments were incubated in water-bath at $38^{\circ} \mathrm{C}$ for $4 \mathrm{~h}$ and manually agitated at each 15 to $20 \mathrm{~min}$.

Acrosome reaction evaluations were carried out using $10 \mu \mathrm{L}$-semen smears that had been stained with Trypan-Blue/Giemsa (TB) according to Kovacs and Foote (1992). In each smear layer, 200 spermatozoa were analized and eight distinct spermatozoal classes were identified: 1) intact alive (IA); 2) damaged alive (DA); 3) alive with detached acrosome (SA); 4) alive with acrosome reaction (RA); 5) intact dead (ID); 6) damaged dead (DD); 7) dead with detached acrosome (SD); and 8) dead with degenerate acrosome (RD).
Cumulus oocytes complexes (COC) were obtained by aspiration of $2-8 \mathrm{~mm}$ follicles from the ovaries of slaughtered cows up to $3 \mathrm{~h}$ after slaughter. The COC were selected and transferred into microdroplets of TCM-199 medium (GIBCO BRL, Grand Island, USA) supplemented with $10 \%$ bovine fetal serum; $26.2 \mathrm{mM} \mathrm{NaHCO} 3 ; 0.2 \mathrm{mM}$ of sodium pyruvate; $75 \mu \mathrm{g}$ Kanamicina/mL; $0.5 \mu \mathrm{g}$ FSH $/ \mathrm{mL} ; 100 \mu \mathrm{g}$ $\mathrm{eCG} / \mathrm{mL}$, and $1 \mu \mathrm{g}$ estradiol $/ \mathrm{mL}$ (maturation medium) and cultivated for $24 \mathrm{~h}$ at $38.5^{\circ} \mathrm{C}$ in atmosphere of $5 \%$ of $\mathrm{CO}_{2}$ in air and relative humidity of $100 \%$. The semen straws were thawed at $35^{\circ} \mathrm{C}$ for $20 \mathrm{sec}$ and the semen was deposited on a discontinuous Percoll ${ }^{\circledR}$ (Amersham Pharmacia Biotech AB, Uppsala, Sweden) density gradient. To prepare the gradient, $2.0 \mathrm{~mL}$ of $45 \%(\mathrm{v} / \mathrm{v})$ Percoll, diluted with HEPES $(10 \mathrm{mM})$ buffered TALP, was placed over $2.0 \mathrm{~mL} 90 \%(\mathrm{v} / \mathrm{v})$ Percoll for 30min at $700 \mathrm{x} \mathrm{g}$ at $22^{\circ} \mathrm{C}$. Viable sperm from the pellet had concentration adjusted to $25 \times 10^{3} \mathrm{sperm} / \mathrm{mL}$ and $4 \mu \mathrm{L}$ of those were added to each microdroplets $(100 \mu \mathrm{L})$ with IVF medium (TALP medium supplemented with $2.7 \mu \mathrm{g}$ penicillin, $10 \mu \mathrm{g}$ hypotaurine, $0.33 \mu \mathrm{g}$ epinephrine, and 10UI heparin $/ \mathrm{mL}$ ). The final sperm concentration in the fertilization microdroplets was $100 \times 10^{3}$ sperm and they remained incubated for 60 to $90 \mathrm{~min}$ for sperm capacitation. The oocytes were matured for 24 to $25 \mathrm{~h}$ and washed three times in TCM-199 culture medium (GIBCO BRL) supplemented with $25 \mathrm{mM}$ HEPES, $0.2 \mathrm{mM}$ sodium pyruvate, and $0.3 \%$ BSA $(10 \mathrm{mg} / \mathrm{mL}$; fraction V, fatty acid free - Inlab, Sao Paulo, Brazil) and once in microdroplet of IVF medium. The occytes and sperm (approximately 25 oocytes per microdroplet of $100 \mu \mathrm{L}$ ) were incubated for 10 to $24 \mathrm{~h}$ at 38.5 to $39^{\circ} \mathrm{C}$ in $5 \%$ of $\mathrm{CO}_{2}$ in air. After fertilization, the presumed zygotes were co-cultivated with granulose cells, performed in a humidified atmosphere of 5\% $\mathrm{CO}_{2}$, in air, $100 \%$ of relative humidity and at temperature of 38.5 to $39^{\circ} \mathrm{C}$. After $33 \mathrm{~h}$ of culture, the cleavage rate was evaluated and embryos were cultivated replacing the medium at each $48 \mathrm{~h}$ until the seventh day when blastocysts rate was evaluated. Three repetitions of the experiment were performed in different days for each bull (with different semen batches for each repetition) and 40 oocytes were utilized per repetition. The order of utilization of the bull semen and batches were randomly in order to 
avoid a possible IVF effect (day/oocyte) in the semen evaluation.

The variance analysis of the acrosomal reaction and IVP data was performed by Tukey's Test. The inter-relations between the acrosomal reaction and IVF variable were determined by correlation analysis (Pearson's) and linear regression study (stepwise regression analysis). Data obtained from the experimental procedure were analyzed using Statistical Analysis System software (SAS Institute - Cary, NC, USA), 6.12 version. All statistical analyses were calculated with a significance level of 5\% (differences were considered significant at $\mathrm{P}<0.05$ ).

\section{RESULTS}

The in vitro AR induction was analyzed by light microscopy utilizing TB stain (Kovacs and Foote, 1992). The analyses of the different treatments demonstrate a significant difference $(\mathrm{P}<0.01)$ to the percentage of the RA sperm between the THL treatment $(43 \%)$ and the other treatments (TALP:36\%, TH:39\%, and TL:36\%) at hour zero. After $4 \mathrm{~h}$ of incubation, a significant difference $(\mathrm{P}<0.01)$ could be observed in the percentage of the reacted alive sperm to the treatments which received heparin (TH:56\% and THL:57\%) in relation to the others (TALP:52\% and TL:53\%). The heparin treatment (TH) proved to be an important inductor of acrosomal reaction in relation to the control treatment $(\mathrm{P}<0.01)$ after $4 \mathrm{~h}$ of incubation and the increase in the percentage of reacted alive spermatozoa was $5.5 \%$. The LPC treatment (TL) was no significantly different from control treatment neither 0 nor at $4 \mathrm{~h}$ in relation to the proportion of reacted alive spermatozoa. Also, no significant difference was observed from the results of treatments with heparin and LPC (THL) in relation to heparin treatment $(\mathrm{TH})$ after incubation for $4 \mathrm{~h}$. LPC did not prove to have the expected inductor effect, presenting similar results to the control treatment ( $T L=T A L P)$, or to the treatment with heparin $(\mathrm{THL}=\mathrm{TH})$. The different treatments did not express any negative effect on the sperm viability during the $4 \mathrm{~h}$ of incubation. There were no variations in the average of the dead sperm (13\%) for the different treatments.

The means of the cleavage and blastocyst rates were compared by Turkey test at significance level of $5 \%$. It was observed a difference $(\mathrm{P}<0.05)$ in the cleavage and blastocyst rates among bulls (Table 1).

Table 1. Means of cleavage and blastocyst rates in percentages for in vitro produced bovine embryos that had been fertilized using thawed, cryopreserved sperm from ten Nelore bulls

\begin{tabular}{ccc} 
Bull & $\begin{array}{c}\text { Means of } \\
\text { cleavage rates }\end{array}$ & $\begin{array}{c}\text { Means of } \\
\text { blastocyst rates }\end{array}$ \\
\hline 1 & $52.1 \mathrm{bcd}$ & $32.6 \mathrm{bc}$ \\
2 & $68.6 \mathrm{ab}$ & $49.1 \mathrm{a}$ \\
3 & $65.8 \mathrm{abc}$ & $42.2 \mathrm{ab}$ \\
4 & $65.4 \mathrm{abc}$ & $46.6 \mathrm{ab}$ \\
5 & $43.6 \mathrm{~d}$ & $36.3 \mathrm{abc}$ \\
6 & $68.7 \mathrm{ab}$ & $36.5 \mathrm{abc}$ \\
7 & $50.9 \mathrm{~cd}$ & $32.5 \mathrm{bc}$ \\
8 & $61.0 \mathrm{abc}$ & $38.2 \mathrm{abc}$ \\
9 & $71.1 \mathrm{a}$ & $41.7 \mathrm{ab}$ \\
10 & $61.4 \mathrm{abc}$ & $25.7 \mathrm{c}$ \\
\hline Average & 60.8 & 38.1 \\
\hline
\end{tabular}

Meand followed by different superscripts (a,b,c,d) within the same column differ significantly $(p<0.05)$.

The correlations obtained among thawed, cryopreserved semen samples from ten Nelore bulls in the different sperm classes (for each treatment at 0 and $4 \mathrm{~h}$ incubation) and cleavage and blastocyst rates are described in Tables 2 and 3 , respectively. Highly negative correlations were observed between the acrosomal intact alive classes for the different sperm treatments and embryonic cleavage rates (Table 2) as well as the acrosomal intact alive classes and the blastocyst development rates (Table 3).

Table 2. Correlation coefficients (r values) between the only significant classification of sperm function, i.e. intact alive sperm (IA) and cleavage rates of in vitro produced embryos for different media treatments (a) at 0 and $4 \mathrm{~h}$ incubation

\begin{tabular}{ccccccccc}
\hline & TALP 0h & TALP 4h & TH 0h & TH 4h & TL 0h & TL 4h & THL 0h & THL 4h \\
\hline IA & $-0,76^{*}$ & $-0,75^{*}$ & $-0,81^{* *}$ & Ns & $-0,80^{*}$ & $-0,67^{*}$ & $-0,73^{*}$ & Ns \\
\hline
\end{tabular}

*P<0.05; **P $<0.01 ;$ ns: not significant.

(a): TALP (TALP medium), TH (TALP medium $+10 \mu \mathrm{g}$ heparin), TL (TALP medium $+100 \mu \mathrm{g}$ LPC), THL (TALP medium $+10 \mu \mathrm{g}$ heparin $+100 \mu \mathrm{g}$ LPC) 
Table 3. Correlation coefficients ( $\mathrm{r}$ values) between certain sperm class variables (a) and the developmental rates of blastocysts in vitro produced using different treatments (b) after 0 and $4 \mathrm{~h}$ incubation

\begin{tabular}{ccccccccc}
\hline & TALP 0h & TALP 4h & TH 0h & TH 4h & TL 0h & TL 4h & THL 0h & THL 4h \\
\hline IA & $-0,740^{*}$ & $-0,811^{* *}$ & $-0,719^{*}$ & Ns & $-0,669^{*}$ & $-0,745^{*}$ & ns & Ns \\
RA & Ns & $0,645^{*}$ & Ns & Ns & ns & ns & ns & Ns \\
\hline
\end{tabular}

$* \mathrm{P}<0.05 ; * * \mathrm{P}<0.01 ;$ ns: no significant.

(a): IA (intact alive sperm), RA (acrosome-reacted alive sperm);

(b): TALP (TALP medium), TH (TALP medium $+10 \mu \mathrm{g}$ heparin), TL (TALP medium $+100 \mu \mathrm{g}$ LPC), THL (TALP medium $+10 \mu \mathrm{g}$

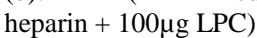

The regression study between induction of the $\mathrm{AR}$ and cleavage found a mathematical model (cleavage $=73.5824-0.3553 \times$ IA TALP $4 \mathrm{~h}$; $* * \mathrm{R}^{2}: 65.93 \%$ ) of simple linear regression that allows to predict the cleavage results utilizing the induction of the AR technique with $65 \%$ of reliability. The regression study between induction of the AR and blastocyst found a mathematical model (blastocyst $=16.2339+$ $0.2777 \times$ RA TH 0 h $+2.4577 \times$ RA TH 4h/RA TH Oh $+0.6033 \times$ RD THL 0h $-0.0972 \times$ RA THL 4h - RA THL 0h; ** $\mathrm{R}^{2}: 99.52 \%$ ) of multiple linear regression that allows to predict the blastocyst results by the induction of the AR technique with $99 \%$ of truthfulness.

\section{DISCUSSION AND CONCLUSION}

The present work proposes the utilization of induction of the AR, evaluated by TB stain, as an alternative in the prediction of the IVP potential in the Nelore breed. The stain technique was efficient not only in the spermatic viability detection but also in the detection of acrosoma presence or absence according to similar results described by Kovacs and Foote (1992).

The heparin confirmed to be an important inductor of acrosomal reaction after $4 \mathrm{~h}$ of incubation in sperm from Bos indicus sires. This finding is according to Parrish et al. (1988) that described that heparin as one of the most efficient agents in the sperm capacitation induction after a minimal exposure of $4 \mathrm{~h}$ in taurine sires. Although the literature describes an important participation of LPC in acrosomal reaction of the in vitro capacitated sperm (Parrish et al., 1988), the results of this work indicate that LPC did not presente the expected inductor effect in the Nelore semen. Therefore, it became clear the necessity of performing other works utilizing LPC as a RAI inductor agent for the Bos indicus in order to detect possible differences between the bovine subspecies in relation to the concentration and methodology of the inductor agent preparation.

This study demonstrated a significant difference in cleavage and blastocyst rates among bulls (Table 1). These findings are in agreement with Ward et al. (2003) who also observed a significant variation in vivo among bulls in those parameters. It can be concluded, that the assessment of the potential fertility of the semen is necessary before performing the IVP. Moreover, according to studies from Januskauskas et al. (2000a,b) with Bos taurus and Stahr et al. (2000) with boars, the present study with Bos Taurus indicus demonstrated a high negative association between the intact alive (IA) sperm class and the cleavage and blastocysts rates. Hence, it can be indicated the importance of this sperm class in the prediction of those fertility parameters.

The negative correlations between IA class and cleavage rate verified in Table 2 indicates that an increase in the percentage of IA sperm cause a reduction in cleavage rate. Similar results were obtained in the correlation between the IA class and blastocyst rates (Table 3), also expressing this negative correlation in relation to this fertility parameter. It could also be verified a positive correlation between the RA class and blastocyst rate after $4 \mathrm{~h}$ of incubation. A possible explanation for the negative correlations between the IA sperm at zero hour of incubation and the fertility rates evaluated, suggests the participation of live sperm which undergo spontaneous acrosome reaction in the fertilization process, as described by Tulsiani et al. (1998). The high negative correlation observed between IA class and cleavage and blastocyst rates confirms its importance in the prediction of bull fertility. 
Lonergan (1994) described that blastocyst rate demonstrated to be more important than cleavage rate in the estimation of in vitro bull fertility. However, the difference in cleavage and blastocyst rates among bulls demonstrated in this study, indicates that the former is a model of better sensibility $(\mathrm{P}<0.05)$ in relation to blastocyst rate $(\mathrm{P}<0.10)$ in the detection of probable differences among semen samples of bulls. In addition, Zhang et al. (1997) described a significant positive correlation between in vitro cleavage rate and in vivo fertility, expressed by the non-return rates after AI.

Amann et al. (1993), Brito et al. (2003), and Gadea (2005) pointed out that the combination of tests to evaluate sperm function is the most reliable approach to increase the accuracy of estimating the potential fertility of semen samples. Rodriguez-Martinez and Barth (2007) also stated that a laboratory test that accurately estimates the potential fertility of a semen sample or a sire is distant and due to the complex nature of male fertility any sought for laboratory method must include testing of most sperm attributes relevant for both fertilization and embryo development.

Nevertheless, the statistical associations (correlation and regression studies) found in this work suggest that $\mathrm{AR}$ induction is a prospective technique in the prediction of IVP results for semen from Nelore bulls. The main advantage of this technique is the facility of execution and lower costs. Therefore, the increasing efficiency and costs reduction in bull selection by utilization of this technique can be a useful tool in the increment of the animal improvement.

\section{ACKNOWLEDGMENTS}

The authors acknowledge FAPESP for the funding supplies 00/05348-5, 04/06044-0, and 05/59357-9.

\section{REFERENCES}

ARRUDA, R.P.; SOUZA, N.L.; MARQUES, A. et al. Evaluation of techiniques using CFDA/PI, H258/FITCPSA and trypan blue/giemsa for assessment of the viability and acrosomal integrity of cryopreserved equine spermatozoa. Theriogenology, v.57, p.477, 2002.
AMANN, R.P.; HAMMERSTEDT, H.P. In vitro evaluation of sperm quality: an opinion. $J$. Androl., v.14, p.397-405, 1993.

BRITO, L.F.C.; BARTHA, A.D.; BILODEAUGOESEELSB, S. et al. Comparison of methods to evaluate the plasmalemma of bovine sperm and their relationship with in vitro fertilization rate. Theriogenology, v.60, p.1539-1551, 2003.

CELEGHINI, E.C.C.; NASCIMENTO, J.; ANDRADE, A.F.C. et al. Use of CMXRos and JC-1 on mitochondrial function evaluation, associated to fluorescent probes to plasmatic and acrosomal membranes evaluation in bovine spermatozoa. Acta Sci. Vet., v.33, p.321 (abstract), 2005.

CHRISTENSEN, P.; WHITFIELD， C.H.; PARKINSON, T.J. In vitro induction of acrosome reactions in stallion spermatozoa by heparin and A23187. Theriogenology, v.45, p.1201-1210, 1996.

FLORMAN, H.M. Sequential focal and global elevations of sperm intracellular $\mathrm{Ca}_{2}+$ are initiated by the zona pellucida during acrosomal exocytosis. Dev. Biol., v.165, p.152-164, 1994.

GADEA, J. Sperm factors related to in vitro and in vivo porcine fertility. Theriogenology, v.63, p.431-444, 2005.

GARNER, D.L.; JOHNSON, L.A. Viability assessment of mammalian sperm using SYBR-14 and propidium iodide. Biol Reprod., v.53, p.276284, 1995.

HILLERY, F.L.; PARRISH, J.J.; FIRST, N.L. Bull specific effect on fertilization and embryonic development in vitro. Theriogenology, v.33, p.249 (abstract),1990.

JANUSKAUSKAS，A.; JOHANNISSON，A.; SODERQUIST, L. et al. Assessment of the fertilizing potential of frozen-thawed bovine sperm by calcium ionophore A23187-induced acrosome reaction in vitro. Theriogenology, v.53, p.859-875, 2000a.

JANUSKAUSKAS, A.; GIL, J.; SODERQUIST, L. et al. Relationship between sperm response to glycosaminoglycans in vitro and non return rates of Swedish dairy AI bulls. Reprod. Domest. Anim., v.35, p.207-212, 2000b. 
KITIYANANT, Y.; CHAISALEE, B.; PAVASUTHIPAISIT, K. Evaluation of the acrosome reaction and viability in buffalo sperm using two staining methods: the effects of heparin and calcium ionophore A23187. Int. J. Androl., v.25, p.215-222, 2002.

KOVACS, A.; FOOTE, R.H., Viability and acrosome staining of bull, boar and rabbit sperm. Biotech. Histochem., v.67, p.119-124, 1992.

KUTVOLGYI, G.; STEFLER, J.; KOVACS, A. Viability and acrosome staining of stallion sperm by Chicago sky blue and Giemsa. Biotech Histochem., v.81, p.109-117, 2006.

LONERGAN, P. The application of in vitro fertilization techniques to the prediction of bull fertility. Reprod. Domest. Anim., v.29, p.12-21, 1994.

OEHNINGER, S.; BLACKMORE, P.; MORSHEDI, M. et al. Defective calcium influx and acrosome reaction (spontaneous and progesterone-induced) in spermatozoa of infertile men with severe teratozoospermia. Fertil. Steril., v.61, p.349-354, 1994.

PARRISH, J.J.; SUSKO-PARRISH, J.; WINER, M.A. et al. Capacitation of bovine sperm by heparin. Biol. Reprod., v.38, p.1171-1180, 1988.

RODRIGUEZ-MARTINEZ, H.; BARTH, A.D. In vitro evaluation of sperm quality related to in vivo function and fertility. Soc. Reprod. Fertil., v.64, Suppl., p.39-54, 2007.

STAHR, B.; BERG, C.; BECHTOLD, B. et al. Relations between the amount of in-vitrocapacitated sperm cells after liquid-preservation and the fertility of AI-boars. In: INTERNATIONAL MEETINGS ON ANIMAL REPRODUCTION, 14., 2000, Stockholm. Proceedings... Stockholm: ICAR. v.2, p.152, 2000.
TARTAGLIONE, C.M.; RITTA, M.N. Prognostic value of spermatological parameters as predictors of in vitro fertility of frozen-thawed bull semen. Theriogenology, v.62, p.1245-1252, 2004.

TULSIANI, D.R.P.; ABOU-HAILA, A.; LOESE, C.R. et al. The biological and functional significance of the sperm acrosome and acrosomal enzymes in mammalian fertilization. Exp. Cell Res., v.240, p.151-164, 1998.

WARD, F.; RIZOS, D.; CORRIDAN, D. et al. Paternal influence on the time of first embryonic cleavage post insemination and the implications for subsequent bovine embryo development in vitro and fertility in vivo. Mol. Reprod. Dev., v.60, p.47-55, 2001.

WARD, F.; RIZOS, D.; BOLAND, M.P. et al. Effect of reducing sperm concentration during IVF on the ability to distinguish between bulls of high and low field fertility: work in progress. Theriogenology, v.59, p.1575-1584, 2003.

ZHANG, B.R.; LARSSON, B.; LUNDEHEIM, $\mathrm{N}$. et al. Relationship between embryo development in vitro and 56-day non return rates of cows inseminated with frozen-thawed semen from dairy bulls. Theriogenology, v.48, p.221$231,1997$. 